Zeszyty Naukowe Szkoły Głównej Gospodarstwa Wiejskiego w Warszawie

Problemy Rolnictwa Światowego tom 18 (XXXIII), zeszyt 4, 2018: 463-472

DOI: 10.22630/PRS.2018.18.4.134

Joanna Szwacka-Mokrzycka', Grzegorz Letkowski ${ }^{2}$

Szkoła Głowna Gospodarstwa Wiejskiego w Warszawie

\title{
Kierunki dostosowań przedsiębiorstw handlowych do wzorców zakupowych konsumentów
}

\section{Directions of Adaptation of Commercial Enterprises to Consumer Purchasing Patterns}

\begin{abstract}
Synopsis. W okresie transformacji polskiej gospodarki, największe zmiany zaszły w systemie dystrybucji. Tak jak w latach 90. XX w. integratorem w łańcuchu żywnościowym był przemys spożywczy, tak w drugiej dekadzie XXI w. funkcję tę pełni handel detaliczny. Wynika to z faktu rosnącej pozycji korporacji transnarodowych w Polsce. Celem przewodnim artykułu jest przedstawienie skali i zakresu zmian w handlu detalicznym w Polsce i określenie kierunku dostosowań przedsiębiorstw handlowych do wzorców zakupowych konsumentów. Punktem wyjścia rozważań jest przedstawienie procesów koncentracji sektora w latach 2012-2016. Następnie poddano analizie kierunki zmian whandlu detalicznym w okresie transformacji gospodarki polskiej. W kolejnej części opracowania przedstawiono dostosowania przedsiębiorstw handlowych do wzorców zakupowych polskich konsumentów.
\end{abstract}

Słowa kluczowe: handel detaliczny, zmiany strukturalne w handlu, wzorce zakupowe konsumentów

\begin{abstract}
During the transformation of the Polish economy, the huge changes took place in the distribution system. In 1990 the integrator in the food chain was the food industry. In the second decade of the 21 st century, the same function is fulfilled by retail trade. This situation is due to the growing position of transnational corporations in Poland. The main goal of the article is to present the scale and scope of changes in retail trade in Poland and to determine the direction of adaptation of commercial enterprises to consumer purchasing patterns. The starting point of consideration is to present the processes of sector concentrations in 2012-2016. Then, the trends of retail trade during the transformation of the Polish economy were analysed. The next part of the study presents adaptations of trade enterprises to the purchasing patterns of Polish consumers.
\end{abstract}

Key words: retail trade, trade structural changes, consumer purchasing patterns

JEL Classification: D12, L81, M39

\section{Wstęp}

W okresie transformacji gospodarki żywnościowej w Polsce, zmiany objęły wszystkie jej ogniwa, przy czym skala zmian była relatywnie największa w dystrybucji. W handlu hurtowym i detalicznym procesy restrukturyzacji rozpoczęły się w latach 90 . i były wynikiem relatywnie największego stopnia koncentracji kapitału. Efekt tych procesów stanowiło pojawienie się na polskim rynku dużych, o wysokim potencjale przedsiębiorstw

${ }^{1}$ dr hab., prof. SGGW, Katedra Polityki Europejskiej i Marketingu SGGW, ul. Nowoursynowska 166, 02-787 Warszawa, e-mail: joanna_szwacka@sggw.pl; https://orcid.org/0000-0001-5197-6212

${ }^{2}$ mgr, Katedra Polityki Europejskiej i Marketingu SGGW, ul. Nowoursynowska 166, 02-787 Warszawa, e-mail: grzegorz letkowski@sggw.pl; https://orcid.org/0000-0002-7619-6412 
handlowych. Rynek polski charakteryzował się wysoką pojemnością i wzrastającą siła nabywczą konsumentów, co sprzyjało rozwojowi konkurencji między przedsiębiorstwami polskimi i zagranicznymi. Istotne zmiany w nowoczesnych formatach handlu detalicznego dokonały się $\mathrm{w}$ drugiej dekadzie XXI wieku. Wynikało to $\mathrm{z}$ tendencji zbliżania się wzorców zakupowych Polaków do tych, jakie są charakterystyczne dla krajów rozwiniętych Unii Europejskiej.

Celem przewodnim artykułu jest przedstawienie skali i zakresu zmian $\mathrm{w}$ handlu detalicznym w Polsce i określenie kierunku dostosowań przedsiębiorstw handlowych do wzorców zakupowych konsumentów. Opracowanie powstało w oparciu o dane wtórne, pochodzące z przeglądu literatury przedmiotu, opracowań Głównego Urzędu Statystycznego oraz raportów agencji badań rynku.

\section{Dotychczasowy stan wiedzy na temat zmian w handlu detalicznym w Polsce}

Problematyka dokonujących się zmian w handlu detalicznym w okresie transformacji gospodarki w Polsce, stała się przedmiotem zainteresowań badawczych wielu naukowców. Szczególne znaczenie $\mathrm{w}$ ocenie roli i pozycji handlu mają prace B. Borusiak, P. Chechelskiego i A. Dąbrowskiej (Borusiak, 2017; Dąbrowska i in., 2015; Chechelski, 2015). Rozwój handlu hurtowo-detalicznego postępował w Polsce przy wykorzystaniu integracji poziomej i pionowej. W ramach interacji poziomej przedsiębiorstwa zrzeszały się na zasadach dobrowolności w celu dokonywania wspólnych zakupów (KłosiewiczGórecka, Wasilik, 2014). Integracja pionowa obejmowała współpracę w obrębie: producent-hurtownik-detalista. W praktyce występuje dążenie do upraszczania tej formuły przez eliminowanie pośredników, co skutkuje powstawaniem tzw. jednostek hurto-detalu (Maleszyk, 2009). Jeśli chodzi o kierunek i dynamikę przekształceń zachodzących w handlu hurtowym i detalicznym w latach 1990-1996, należy zauważyć dystrybutorów zagranicznych, którzy zaczęli podejmować inwestycje w polski handel, począwszy od 1992 roku. W pierwszym etapie były tworzone spółki typu joint-ventures z firmami polskimi, w kolejnym następował ich wykup przez inwestorów zagranicznych. Dystrybutorzy zagraniczni zakładali własne wielkopowierzchniowe sklepy filialne. W efekcie tych działań, na przestrzeni lat 90. i w pierwszej dekadzie XXI wieku, nastąpił dynamiczny wzrost udziału hipermarketów i supermarketów, przesądzając o wysokim poziomie koncentracji handlu detalicznego w Polsce. O budowaniu przewag konkurencyjnych zagranicznych dystrybutorów na polskim rynku przesądzało oferowanie relatywnie niższych cen towarów, wysoka pojemność rynku polskiego i wzrastająca siła nabywcza polskich konsumentów (Szwacka-Mokrzycka, 2017). Sytuacja ta niewątpliwie stanowiła siłę napędową rozwoju konkurencji na polskim rynku między przedsiębiorstwami polskimi i zagranicznymi. Ekspansja podmiotów zagranicznych na polski rynek wpłynęła też na zmianę wzorców zakupowych Polaków, którzy zaczęli preferować wybór form sprzedaży preselekcyjnej (Chechelski, 2014; Dąbrowska i in., 2015).

$\mathrm{Na}$ potrzebę wiązania zmian $\mathrm{w}$ rozwoju handlu detalicznego $\mathrm{z}$ analizą cyklu życia produktu zwraca uwagę Borusiak (2017). Powstawanie nowych formatów odbywa się pod wpływem różnorodnych czynników o charakterze zewnętrznym i wewnętrznym. Koncepcja cyklu życia produktu wskazuje na potrzebę śledzenia zmian w rozwoju handlu detalicznego i dokonywania modyfikacji systemowych, poprzez tworzenie nowych formatów. Wśród 
czynników zewnętrznych dominujące znaczenie mają demograficzno-społeczne i ekonomiczne. Natomiast do czynników wewnętrznych zaliczono: potencjał gospodarczy, pozycję rynkową formatu, kluczowe kompetencje, orientację temporalną oraz strategię przedsiębiorstwa. W drugiej dekadzie XXI wieku obserwuje się na polskim rynku istotne zmiany w nowoczesnych formatach handlu detalicznego. Dotyczą one osłabienia pozycji hipermarketów, przy jednoczesnym wzroście zapotrzebowania na mniejsze formaty. Należy uznać, że rynek hipermarketów w Polsce osiagnął fazę nasycenia i zbliża się do fazy spadku (Mazurkiewicz, 2012). Nastąpił jednocześnie wzrost popytu na produkty oferowane przez sieć dyskontów na skutek rozwoju szerokiego asortymentu produktów marek własnych, utożsamianych przez klientów z relatywnie wysoką jakością. W efekcie przyjętej strategii nastapiło poszerzenie grona klientów dysponujących relatywnie wysokimi dochodami. Na tle prowadzonych analiz można przyjąć, że format dyskontów znajduje się w fazie dojrzałości. Należy ponadto zwrócić uwagę na rozwój w Polsce supermarketów o mniejszej powierzchni sprzedażowej, lokalizowanych blisko miejsc zamieszkania konsumentów, jak też supermarketów z szeroką ofertą artykułów delikatesowych, częstą sygnowanych marką własną o wysokiej jakości (Kłosiewicz-Górecka, 2013).

\section{Procesy koncentracji sektora handlu detalicznego w latach 2012-2016}

Jak już zostało powiedziane, w okresie transformacji polskiej gospodarki, największe zmiany zaszły w systemie dystrybucji. Były one związane z działaniami dostosowawczymi sektora gospodarki żywnościowej do gospodarki rynkowej. Wyrazem tego był wzrastający w latach 90. XX w. udział sektora prywatnego w handlu hurtowym i detalicznym (Dąbrowska $\mathrm{i}$ in., 2015). W drugiej dekadzie XXI w. funkcję integratora w łańcuchu żywnościowym zaczął pełnić handel detaliczny. Wynika to z faktu rosnącej pozycji korporacji transnarodowych $\mathrm{w}$ Polsce. $\mathrm{W}$ ramach działań globalizacyjnych na świecie, w Polsce w badanym okresie zaczęły się pojawiać super i hipermarkety, dominując w sprzedaży detalicznej. Proces koncentracji sprzedaży hurtowej i detalicznej miał swoje nasilenie w latach 1990-2000 i w jego efekcie na polskim rynku funkcjonowały i działaja do dziś sieci sprzedaży dużych formatów. Procesy globalizacji niewątpliwie sprzyjają procesom koncentracji w handlu poprzez fuzje i przejęcia przedsiębiorstw. Począwszy od 2009 roku, czyli w okresie dekoniunktury na rynku światowym, sukces rynkowy większość KTN zawdzięczało działaniom na rynkach wschodzących, do których należy zaliczyć: kraje Ameryki Południowej, Bliskiego Wschodu, Azji i Europy Wschodniej. Koncentracja handlu w drugiej dekadzie 21. wieku została przyśpieszona przez zwiększoną ekspansję koncernów światowych, wyposażonych w znaczne zasoby kapitałowe i technologiczne. Sprzyjała temu też homogenizacja wzorców zachowań konsumenckich na skutek przenikania różnych stylów zakupowych w kontekście rynku międzynarodowego. Relatywnie najwyższy stopień koncentracji handlu detalicznego, w latach 2012-2016, miał miejsce w krajach skandynawskich oraz na Litwie i w Słowacji (76-90\%). Na poziomie 58-70\% kształtował się w tym czasie poziom koncentracji w wysokorozwiniętych krajach Europy Centralnej (Francja, Austria, Niemcy) i w Czechach. Zdecydowanie największy stopień rozproszenia handlu detalicznego w analizowanym okresie, wystapił w Polsce, Bułgarii, Grecji, we Włoszech i w Rumunii, stanowiąc 30-49\% udziału w obrotach handlu detalicznego żywnością. Sytuację tą należy wiązać z dużym udziałem w strukturze handlu tych krajów, małych, rodzinnych przedsiębiorstw handlowych - tabela 1. 
Tabela 1. Stopień koncentracji sektora handlu detalicznego w Europie w latach 2012-2016

Table 1. The level of the retail sector concentration in Europe in 2012-2016

\begin{tabular}{l|ccccc}
\hline \multicolumn{1}{c|}{ Kraj } & 2012 & 2013 & 2014 & 2015 & 2016 \\
\hline Austria & 69,7 & 71,8 & 72,5 & 73,6 & 75,8 \\
Bułgaria & 31,6 & 32,3 & 34,6 & 36,8 & 36,6 \\
Chorwacja & 48,7 & 50,6 & 55,8 & 53,5 & 54,4 \\
Czechy & 64,6 & 65,5 & 69,8 & 70,6 & 71,2 \\
Dania & 76,4 & 78,1 & 78,7 & 79,1 & 78,9 \\
Francja & 58,1 & 59,5 & 60,5 & 60,2 & 59,8 \\
Grecja & 33,3 & 30,6 & 32,6 & 34,6 & 34,4 \\
Hiszpania & 41,4 & 41,4 & 43,1 & 43,4 & 43,3 \\
Litwa & 76,5 & 77,0 & 78,2 & 78,2 & 77,1 \\
Niemcy & 69,2 & 69,8 & 70,3 & 70,6 & 70,7 \\
Norwegia & 83,2 & 80,4 & 81,3 & 86,2 & 90,5 \\
Polska & 30,9 & 41,8 & 46,5 & 47,3 & 48,7 \\
Portugalia & 50,4 & 50,8 & 51,9 & 52,6 & 53,2 \\
Rumunia & 33,8 & 38,1 & 39,4 & 40,9 & 43,3 \\
Słowacja & 70,2 & 71,3 & 71,5 & 72,8 & 73,1 \\
Wegry & 57,0 & 55,0 & 56,7 & 56,5 & 56,5 \\
Wielka Brytania & 62,8 & 61,4 & 60,4 & 59,5 & 58,8 \\
Włochy & 32,8 & 34,1 & 35,7 & 35,6 & \\
\hline
\end{tabular}

Źródło: opracowanie na podstawie Borusiak, 2017.

Kraje o najwyższym rozproszeniu handlu detalicznego, charakteryzowały się zróżnicowaną dynamiką zmian w analizowanym okresie. Relatywnie najwyższą dynamiką wzrostu charakteryzowała się Polska, gdzie zaobserwowano wzrost udziału o ponad 35\%, Rumunia - o 25\% i Norwegia o 10\%. Należy zauważyć, iż w Polsce, mimo wysokiej dynamiki wzrostu w analizowanym okresie, handel wciąż jest rozdrobniony. Nieznaczny spadek udziału pięciu największych firm w obrotach handlu żywnością, wystąpił na Węgrzech i w Wielkiej Brytanii. W pozostałych krajach utrzymana została stabilna pozycja sprzedażowa badanych firm (tabela 1). Przyczyny przyśpieszenia procesów koncentracji handlu w krajach transformacji (Polska, Rumunia) należy wiązać z napływem inwestycji zagranicznych o zasięgu globalnym z większym nasileniem, niż w pozostałych krajach o ustabilizowanej strukturze handlu detalicznego. Sytuacja ta spowodowała istotne zmiany strukturalne w handlu, wyraźne odejście od dominowania małych, rodzinnych sklepów na rzecz preferowania sprzedaży przez sieć dyskontów. W krajach skandynawskich na przestrzeni pierwszej i drugiej dekady XXI wieku zaobserwowano utrwalenie się tendencji koncentracji handlu detalicznego na relatywnie najwyższym poziomie w systemie gospodarki europejskiej. Natomiast w krajach o silnych konotacjach kulturowych, czego przykładem są Włochy, rozwija się przede wszystkim handel rodzinny. 


\section{Zmiany strukturalne w handlu detalicznym w latach 1995-2015}

Rozwój handlu detalicznego w Polsce, mimo, iż następował pod wpływem KTN, w dużej mierze pozostaje pod wpływem rodzimych przedsiębiorstw handlowych. Dysponują one niewątpliwie lepszą wiedzą na temat preferencji konsumentów, ich nawyków konsumpcyjnych i upodobań. Dotyczy to zwłaszcza konsumentów odznaczających się silnym etnocentryzmem w kształtowaniu swoich wzorców spożycia. Oczywiście wiele korporacji transnarodowych stosuje na polskim rynku strategie dostosowawcze do potrzeb rynku lokalnego, przede wszystkim w zakresie kształtowania oferty produktowej i sposobów komunikacji marketingowej. Rynek artykułów spożywczych w Polsce odznacza się relatywnie wysokim poziomem nasycenia potrzeb, zatem nie podlega istotnym zmianom w zależności od sytuacji dochodowej konsumentów. Przemawiają za tym wyniki badań elastyczności dochodowej wydatków i spożycia żywności prowadzonych w przekroju kategorii produktowych. Nastąpiło obniżenie współczynników elastyczności w każdej z analizowanych grup, przy czym skala tego spadku jest zróżnicowana. Świadczy to o wzrastającym stopniu nasycenia potrzeb żywnościowych w pierwszej i drugiej dekadzie XXI wieku. Relatywnie największe obniżenie współczynników w analizowanym okresie wystąpiło w grupie wydatków odpowiadających zaspokojeniu potrzeb niższego rzędu. Ten sam kierunek zmian wystapił w odniesieniu do współczynników elastyczności dochodowej spożycia żywności dla grup produktów. Natomiast w odniesieniu do produktów zaspokajających potrzeby podstawowe (o relatywnie wysokim poziomie przetworzenia) elastyczność dochodowa wydatków i spożycia utrzymuje się na zbliżonym poziomie w relacji do pierwszej dekady XXI wieku. Wynika to z faktu stabilizacji wydatków na produkty wysoko przetworzone w latach 20102017. Przyczyn tej sytuacji należy upatrywać w zmianie stylu życia i wzorców konsumpcji Polaków oraz wzroście zapotrzebowania na produkty żywnościowe wysokiej jakości. Zmiany jakościowe w handlu detalicznym w Polsce są wyrazem toczącej się konkurencji pomiędzy krajowymi podmiotami a zagranicznymi. Na przestrzeni pierwszej i drugiej dekady XXI w. istotnie wzrósł poziom integracji krajowych handlowców poprzez tworzenie firm franchisingowych i partnerskich. Niewątpliwie firmy $\mathrm{z}$ kapitałem zagranicznym dysponują znacznie większą siłą kapitałową i budują swoje przewagi konkurencyjne w oparciu o nowoczesne, wielkopowierzchniowe obiekty handlowe, jak też atrakcyjne warunki zakupu. Należy podkreślić, że zagraniczne sieci handlowe w XXI wieku nadal mają decydujaccy wpływ na zmiany w strukturze powierzchni sprzedażowej sklepów, udział w sprzedaży poszczególnych „formatów” (Chechelski, 2015; Rynek Wewnętrzny, 2017). W drugiej dekadzie XXI wieku w handlu detalicznym produktami spożywczymi dokonują się istotne zmiany w ujęciu jakościowym, jak i ilościowym. W pierwszym wymiarze dotyczą one systemu zarządzania jednostkami handlowymi, w drugim zaś struktury handlu. Na przestrzeni lat 1995-2015 na polskim rynku pojawiły się wszystkie nowe istniejące w krajach rozwiniętych formaty, tj.: hipermarkety, dyskonty, supermarkety, sklepy typu „convenience” i internetowe (e-handel). W Polsce, należącej do krajów rozwijających się, wejście nowych formatów, było ściśle związane z poziomem rozwoju gospodarczego kraju, szacowaniem potencjalnego popytu przez firmy międzynarodowe. Temu była podyktowana stopa inwestowania i szacowanie ryzyka z tym związanego, przez globalne korporacje handlowe. Polska stwarzała korzystne warunki dla pozyskania kapitału zagranicznego, zatem bariery wejścia na nasz rynek i podejmowanie inwestycji w tym zakresie nie było obciążone dużym ryzykiem. Na polskim rynku w I i II 
dekadzie XXI wieku dokonały się istotne zmiany w nowoczesnych formatach handlu detalicznego (tabela 2).

Tabela 2. Sprzedaż detaliczna produktów spożywczych w ujęciu kanałów dystrybucji w latach 2004 i 2014

Table 2. Retail sales of food products by distribution channels in years 2004 and 2014

\begin{tabular}{l|cccc}
\hline \multicolumn{1}{c|}{ Wyszczególnienie } & Wartość sprzedaży (mld zł) & \multicolumn{2}{c}{ Struktura rynku (\%) } \\
& 2004 & 2014 & 2004 & 2014 \\
\hline Hipermarkety & 21,9 & 30,4 & 17,0 & 15,8 \\
Supermarkety & 14,4 & 37,9 & 11,2 & 19,7 \\
Sklepy dyskontowe & 10,1 & 52,8 & 7,9 & 27,5 \\
Małe sklepy / convenience & 9,5 & 26,4 & 7,4 & 13,8 \\
Niezależne sklepy spożywcze & 51,8 & 28,5 & 40,2 & 14,8 \\
Specjalistyczne sklepy spożywcze & 12,9 & 10,2 & 10,0 & 5,3 \\
Pozostałe & 8,1 & 6,0 & 6,3 & 3,1 \\
OGÓłEM & 128,7 & 192,2 & 100,0 & 100,0 \\
\hline
\end{tabular}

Źródło: Zatoński, 2015.

Jest to wynikiem dużej konkurencji, przejawiającej się zarówno na polu krajowych dystrybutorów, jak i zagranicznych. Jedną z najstarszych form handlu detalicznego jest hipermarket, powstały w 1963 roku. Na polskim rynku funkcjonują największe globalne korporacje handlowe, jak: Carrefour, Tesco, Leclerc, Auchan oraz Grupa Schwarz (Kaufland). Udział tych sieci w formacie hipermarketów stanowił w 2013 roku, 85\%. W drugiej dekadzie XXI w. obserwujemy w Polsce stopniowe obniżanie się pozycji hipermarketów na polskim rynku. Świadczy o tym spadek ich udziału w rynku z $17.0 \%$ w 2004 do $15.8 \%$ w 2014 [Zatoński 2015]. Jest to wynikiem przede wszystkim zaostrzającej się konkurencji cenowej ze strony sieci dyskontów i supermarketów, jak też zmian we wzorcach zakupowych konsumentów. Sytuacja ta wpłynęła na modyfikację strategii sprzedażowych właścicieli hipermarketów. Zmiany te przejawiały się głównie we wprowadzaniu nowych form hipermarketów typu dyskontowego (Tesco), jak też prowadzenie strategii niskich cen (Leclerc, Auchan). Działania te spowolniły spadek sprzedaży, ale nie będą przynosiły spodziewanych efektów w długim okresie czasu. Badania preferencji konsumenckich wskazują na potrzebę szerszego uwzględnienia w działaniach dostosowawczych wygody zakupu i oszczędności czasu. Zatem należy uznać, że w warunkach polskich rynek hipermarketów osiągnął fazę nasycenia i zbliża się do fazy spadku.

Kolejny omawiany format stanowią sklepy dyskontowe o profilu spożywczym, których powstanie jest datowane na 1970 rok. Nastapił wyraźny wzrost udziału dyskontów w handlu detalicznym żywnością w Polsce z 7.9\% w 2004 do 27.5\% w 2014 roku (Zatoński, 2015). W kolejnych latach można zaobserwować tendencję wzrostową tego formatu do ponad 30\% udziałów. Dane te potwierdzają kierunek rozwoju tego typu formatu w innych krajach europejskich. Ten dynamiczny rozwój sklepów tego formatu był przede wszystkim wywołany poszerzeniem grona nabywców produktów oferowanych przez dyskonty. W drugiej dekadzie XXI wieku segment nabywców został poszerzony o klientów o wyższych dochodach, niż to miało miejsce na początku działalności tego formatu w Polsce. Marki własne oferowane przez sieć dyskontów są współcześnie postrzegane jako 
produkty wysokiej jakości, gdyż są pozycjonowane w różnych segmentach cenowych, w tym $\mathrm{w}$ segmencie premium. Wynika to głównie $\mathrm{z}$ forsowania przez sklepy szerokiego asortymentu produktów marek własnych, utożsamianych przez klientów z relatywnie wysoką jakością i przystępną ceną. Wprowadzane są też do asortymentu znane produkty markowe, szeroka oferta produktów świeżych. Na rynku polskim wiodące znaczenie mają Biedronka i Lidl. Jak szacują eksperci, dyskonty obecnie znajdują się w fazie dojrzałości, $\mathrm{z}$ uwagi na rosnącą konkurencję ze strony innych formatów.

W latach 2004-2014 nastapił też dynamiczny rozwój formatu convenience, małych sklepów spożywczych, zlokalizowanych w pobliżu miejsca zamieszkania. Należą do nich sklepy charakteryzujące się relatywnie małą powierzchnią sprzedaży, ale o wydłużonych godzinach pracy, także w dni świąteczne ( $\mathrm{w}$ stosunku do pozostałych formatów). Przeważnie działają one w systemie franczyzowym. Udział w rynku sklepów convenience, wzrósł z 7.4\% w 2004 do 13.8\% w 2014 (Zatoński, 2015).

\section{Dostosowania przedsiębiorstw handlowych do wzorców zakupowych konsumentów}

Wzorce zakupowe stanowią utrwalone zachowania rynkowe konsumentów i są kształtowane przez następujące czynniki:

- Częstotliwość dokonywanych zakupów;

- Wielkość jednorazowego zakupu;

- Typ wybieranego sklepu;

- Wrażliwość na działania promocyjne.

Poznanie zmian dokonujących się we wzorcach zakupowych konsumentów wiąże się z potrzebą prowadzenia badań rynkowych o różnorodnym charakterze. Na ich podstawie można ustalić, czym kieruje się konsument w procesie podejmowania decyzji zakupowych. Wyniki badań konsumenckich wskazują, że wzorce zakupowe Polaków pozostają pod wpływem zróżnicowanego układu preferencji nabywczych (Górska-Warsewicz, 2009; Kłosiewicz-Górecka, 2013). Należy tu uwzględnić:

- Dogodną lokalizację sklepu (w pobliżu miejsca zamieszkania) i elastyczne godziny otwarcia;

- Zróżnicowaną, wysokiej jakości ofertę produktów;

- Zapotrzebowanie na produkty o wysokim stopniu przetworzenia (convenience food) i usługi gastronomiczne;

- Zapotrzebowanie na produkty prozdrowotne;

- Wygodę zakupu;

- Nowoczesne formy komunikacji marketingowej.

Dokonujące się zmiany we wzorcach konsumpcyjnych, a w szczególności rozwój trendów wygody i prozdrowotności, wymagają dostosowań w obszarze przedsiębiorstw przetwórczych i handlowych. Obejmują one głównie: zróżnicowanie struktury asortymentowej produktów żywnościowych, poprawę ich jakości, jak też wdrażanie innowacyjności i wzmocnienie działań marketingowych ukierunkowanych na budowanie wizerunku rynkowego. Próbę dostosowania się przedsiębiorców do nowych wzorców zakupowych konsumentów stanowią zmiany w strukturze handlu detalicznego w Polsce na 
przełomie pierwszej i drugiej dekady XXI wieku. Odpowiedzią na te potrzeby jest właśnie rozwój formatu sklepów dyskontowych, typu convenience oraz sklepów branżowych.

Wyrazem wzrostu zapotrzebowania konsumentów o mniej zasobnych portfelach na produkty relatywnie wysokiej jakości, ale sprzedawane po niskiej cenie (sygnowane marką własna) jest rozwój sieci dyskontowych. Współcześnie coraz większego znaczenia w kształtowaniu wzorców zakupowych Polaków, nabierają sklepy convenience. Małe osiedlowe punkty sprzedaży, zdobywają coraz większą popularność, ze względu na możliwość dokonywania zakupów o charakterze podstawowym. Wysoki relatywnie popyt na produkty oferowane przez tą sieć sklepów jest wynikiem ich dużej elastyczności w dostosowywaniu się do potrzeb i preferencji miejscowych klientów. Asortyment tych sklepów jest często wspomagany oferowaniem przez nie dodatkowego pakietu usług gastronomicznych.

Zmiany zachowań zakupowych Polaków wskazują, że w tym kierunku powinny też podazżać inne formaty. Wyrazem tego są też działania dużych korporacji, sprowadzające się do modyfikacji strategii sprzedażowych w zakresie powoływania mniejszych sklepów (np. Tesco, Carrefour, Grupa Schwarz). Za tym kierunkiem zmian przemawiają dane wskazujące na podwojenie liczby tego typu sklepów w latach 2010-2015. W tym formacie na polskim rynku działa przede wszystkim sieć Żabka. Należy nadmienić, że oferta sklepów convenience jest $\mathrm{z}$ reguły droższa od sprzedawanej $\mathrm{w}$ dyskontach, przy jednocześnie znacznie wężzzym asortymencie oferowanych produktów. Niemniej przewaga konkurencyjna tego typu formatu wynika przede wszystkim ze zmiany wzorców zakupowych Polaków w kierunku preferowania wolnego czasu i komfortu zakupów, nawet za poniesienie wyższych wydatków. Sytuacja ta jest też przejawem kontynuacji przez Polaków pewnej tradycji opartej na przyzwyczajeniu do robienia zakupów w małych sklepach, zlokalizowanych w bliskiej odległości od miejsca zamieszkania.

Wzrasta też zapotrzebowanie na rozwój sklepów branżowych $\mathrm{z}$ artykułami żywnościowymi o wąskiej specjalizacji, jak piekarniczo-ciastkarskie, $\mathrm{z}$ napojami alkoholowymi, mięsne, owocowo-warzywne, supermarketów z szeroką ofertą artykułów delikatesowych (jak Alma, Bomi, Piotr i Paweł), z ofertą produktów świeżych, często sygnowanych marką własną o wysokiej jakości.

Przejawem trendów wygody jest też wzrost wśród Polaków zainteresowania dokonywaniem zakupów przez Internet. Dotyczy to zwłaszcza produktów żywnościowych o relatywnie długim okresie trwałości, możliwych do przechowywania, jak tez napojów. E-handel jest współcześnie najbardziej rozwojową formą handlu. Przemawiają za tym następujące argumenty: oszczędność czasu, wygoda zakupu oraz porównywalność cen w relacji do tradycyjnych formatów.

Na zróżnicowanie oferty produktowej wpływa też rozwój trendu prozdrowotności. Świadczy o tym wzrost popytu na warzywne soki i kiszonki, polskie wyroby lokalne i regionalne. Wzrasta też popyt konsumencki na żywność funkcjonalną, a w ramach tej oferty, na bakalie, stanowiące zdrową przekąskę (alternatywę dla słodyczy i słonych przekąsek). Produkty te rekomendowane są do spożycia przez znanych szefów kuchni i blogerów, nie tylko ze względu na walory smakowe, ale też wsparcie profilaktyki wielu chorób układu pokarmowego oraz nowotworowych.

Dostosowania przedsiębiorstw handlowych do zmian zachodzących we wzorcach zakupowych polskich konsumentów obejmują też sposoby komunikacji marketingowej. Wyrazem tego jest wykorzystanie $\mathrm{w}$ promocji marki zarówno konwencjonalnych, jak i niekonwencjonalnych form promocji. Coraz większą rolę w budowaniu relacji z klientem 
odgrywają: marketing internetowy, mobilny i media społecznościowe oraz programy lojalnościowe.

\section{Podsumowanie}

Rozwój handlu detalicznego w Polsce w okresie transformacji gospodarczej wskazuje na wysoki poziom jego unowocześnienia i duże zróżnicowanie formatów handlu. Priorytetowe znaczenie w rozwoju handlu detalicznego mają sklepy wygodnego zakupu oraz internetowe. Przedstawione zmiany $\mathrm{w}$ handlu są wywołane przeformułowaniem układu preferencji polskich konsumentów, jak też zaostrzającą się konkurencją pomiędzy poszczególnymi formatami handlu. Efektem działań konkurencyjnych pomiędzy korporacjami handlowymi a globalnymi przedsiębiorstwami przemysłu spożywczego jest rozwój oferty produktów sygnowanych markami własnymi. Przedstawione działania ze strony handlowców stanowią odpowiedź na zmieniające się potrzeby konsumentów. Współczesny konsument podejmuje coraz bardziej przemyślane decyzje zakupowe, oparte Współczesny konsument opiera swoje decyzje zakupowe nie tylko na niskiej cenie, ale na uwzględnianiu relacji ceny do jakości produktu (model „smart” zakupów). Uwzględnia on w dokonywaniu wyborów konsumenckich: składu produktu, jego jakości, działań promocyjnych prowadzonych przez przedsiębiorców i preferowaniu produktów polskiego pochodzenia.

\section{Bibliografia}

Borusiak, B. (2017). Handel detaliczny żywnością w wybranych krajach europejskich (Food retailing in selected European countries). W: Raporty, Instytut Badań Rynku, Konsumpcji i Koniunktur - Państwowy Instytut Badawczy, Warszawa.

Chechelski, P. (2015). Ewolucja łańcucha żywnościowego (Evolution of the food chain). W: Przemysł spożywczy - makrootoczenie, inwestycje, ekspansja zagraniczna (Food industry-macroenvironment, investments, foreign expansion), red. I. Szczepaniak, K. Firlej, UEK, IERiGŻ-PIB, Kraków-Warszawa, 1-18.

Chechelski, P. (2014). Znaczenie handlowych korporacji transnarodowych w handlu żywnościa (The importance of commercial transnational corporations in food trade). Roczniki Naukowe SERiA, 16(4), 74-79.

Dąbrowska, A., Bylok, F., Janoś-Kresło, M., Kiełczewski, D., Ozimek, I. (2015). Kompetencje konsumentów. Innowacyjne zachowania. Zrównoważona konsumpcja (Consumer competence. Innovative behaviors. Sustainable consumption). PWE, Warszawa.

Górska-Warsewicz, H. (2009). Marka jako narzędzie kształtowania przewagi konkurencyjnej przedsiębiorstw sektora żywnościowego (Brand as a tool for shapingthe competitive advantage of enterprises in the food sector). Prace i Materiały Wydziału Zarzqdzania Uniwersytetu Gdańskiego, 2(2), 535-543.

Kłosiewicz-Górecka, U., Wasilik, K. (2014). Dylematy niezależnych sieciowych przedsiębiorstw handlowych w okresie chwiejnego rozwoju gospodarczego (Dilemmas of independent network trading companies during the period of instable economic development). Zeszyty Naukowe Uniwersytetu Szczecińskiego, Problemy Zarzadzania, Finansów i Marketingu, 823 (34), 75-87.

Kłosiewicz-Górecka, U. (2013). Struktura handlu detalicznego w Polsce a preferowane przez konsumentów miejsca zakupu FMCG (The structure of retail trade in Poland and the places of FMCG purchases preferred by consumers), Konsumpcja i Rozwój 2(5), 133-145.

Kłosiewicz-Górecka, U. (2013). Zmiany w handlu detalicznym i hurtowym (Changes in retail and wholesale trade). Przemyst Spożywczy, 7, 2-8

Komor, M. (2013). Handel detaliczny na Eurorynku - internacjonalizacja i koncentracja (Retail trade on Euromarket - internationalization and concentration), Zeszyty Naukowe Uniwersytetu Szczecińskiego. Problemy Zarzqdzania, Finansów i Marketingu, 776(31), 65-77. 
Koniorczyk, G. (2014). Smart shopping a zachowania zakupowe konsumentów (Smart shopping and shopping behawior of consumers). Handel Wewnętrzny, 3(35), 15-24.

Kozłowski, W. (2013). Formy konkurencji a rynkowe efekty reklamy (Forms of competition and market effects of advertising). Wydawnictwo UWM w Olsztynie.

Maleszyk, E. (2009). Zmiany w procesach koncentracji i integracji handlu w Polsce (Changes in the processes of concentration and integration of trade in Poland). Gospodarka Narodowa, 5-6, 113-131.

Mazurkiewicz, P. (2012). Upadek “Bomi”, czyli bankructwo z wyższej półki (The fall of „Bomi”, or high-end bankruptcy). Parkiet. Pobrano 16 listopada $2015 \mathrm{z}$ : http:// www.parkiet.com/artykul/1272537.Html?p=3.

Rynek Wewnętrzny w 2016 r. (2017). Informacje i opracowania statystyczne GUS (Information and Statistical Studies of the Central Statistical Office). Warszawa.

Szwacka-Mokrzycka, J. (2017). Ewolucja polskiej gospodarki żywnościowej po przystapieniu do UE (The evolution of the Polish food economy after joining the EU). W: A. Chlebicka (red.). Integracja europejska jako determinanta polityki wiejskiej. Aspekty ekonomiczne. Wydawnictwo FAPA, 229-239.

Szwacka-Mokrzycka, J. (2018). Trends in the changes of consumer nutritional needs in Poland in the years 2003 2015. Acta Scientiarum Polonorum. Oeconomia, 17(2), 117-123.

Zatoński, M. (2015). Koniec łatwego rozwoju w handlu (The end of easy trade development). Puls Biznesu, 10(1), $130-149$.

Do cytowania / For citation:

Szwacka-Mokrzycka J., Letkowski G. (2018). Kierunki dostosowań przedsiębiorstw handlowych do wzorców zakupowych konsumentów. Problemy Rolnictwa Światowego, 18(4), 463-472;

DOI: $10.22630 /$ PRS.2018.18.4.134

Boczar P. (2018). Directions of Adaptation of Commercial Enterprises to Consumer Purchasing Patterns (in Polish). Problems of World Agriculture, 18(4), 463-472;

DOI: 10.22630/PRS.2018.18.4.134 